\title{
Out of Abstraction:
}

\section{Merging Experience, Theory, and Praxis as Black Art Therapists}

\author{
Leah Ashanti Amaral ${ }^{1}{ }^{*}$, Johanna Tesfaye ${ }^{2}$ \\ 1 graduate alumnus of the Art Therapy \& Counseling Department, School of the Art Institute, USA \\ 2 graduate student in the Art Therapy \& Counseling Department, School of the Art Institute, USA \\ *leah.a.amaral@gmail.com
}

Received: 1 April 2020 Accepted: 17 January 2021 Published: 20 April 2021

Editors: Marisol Norris, Britton Williams, Leah Gipson Reviewers: Veronica Bohanan, Adam Stevens

\begin{abstract}
This paper describes a collaborative self-reflexive practice using art-making, personal experience, womanist performance pedagogy (WPP), the Black Arts Movement, and poetry as the starting material for inquiry. Through arts-based inquiry, we reflected on our practice and Black personhood as art therapists, artists, and activists. We investigated the concepts of therapeutic and professional space in three areas: negotiating identity, co-creating our therapeutic practice, and making alternatives. We utilized the seven characteristics of WPP proposed by Khalilah Ali in her dissertation 'For Us Poetry is Not a Luxury': A Case Study of Six Black Women Artist-Educator-Activists as a framework, while drawing from care and healing practices from the Black Arts Movement, and using poetry as material. We merge our experience, theory, and action through this collaborative, self-reflexive, exploratory investigation, to better understand how to cultivate subversion and challenge the power structures and systems that we navigate on a daily basis. Our interest in this topic derived from the two alternative spaces that we created during our time as art therapy students: BIPOC Makespace and Sister Circle. We realized that our starting point does not always have to be in relation to whiteness, critiquing whiteness, or talking about our experiences in relation to oppression that has happened in our education. This paper is giving us the opportunity to choose our own starting point and material to investigate, putting Black knowledge, experience, and praxis at the center.
\end{abstract}

Keywords: Black, Experiential, Arts-Based Inquiry, Black Art Therapist, Art Therapy, Poetry

\section{Introduction}

The following text is an experimental writing project that chronicles the authors' art therapy schooling, internship, and work experiences. The authors engaged in collective-reflectivity and memory mapping over the course of a year as a means to build community and witness each other's understanding of place and worlds. We have been 
intentional about creating experimental spaces of care for ourselves and the different communities that we are a part of. This essay is a collage of documentary materials, which include the transcripts of dialogues in these care spaces, personal journal entries, poetry, photos (Figures 1-11), and private conversations with Black women. Through the production of interwoven text, the authors interpret multiple meanings and values that emerge from sustained dialogue and the collective knowing of Black women's sacred work and existence.

Room erupts in laughter.

D. Swan: I don't have to explain it further. But, if someone nodded their head at me, and I ... and they're like ... y'all get it. And that's who I need to, get it. And not everyone needs to try to understand what I'm trying to say. And I think that's when I'm like I came to that "smart enough, thoughtful enough, strong enough" thing. Because we are thoughtful enough and we are smart enough, and it's not our job to make sure or to prove that to anyone else. You know?

Umoja: The bitterness, the bitterness.

The room erupts in laughter

Someone says mmmmmm

Laughter fills the room

Participants make mmmmm sound.

D. Swan: I'm going to go do my dream, my job, you don't know me. You don't know what I'm trying to do with this.

The room fills with laughter.

(Amaral, 2019b, p. 8)

A said the community can smell fear and hesitation, which could mean be assertive or confident instead. Which was funny considering "How to act in the unknown", was to get familiar.

"Fake it till you make it" A said.

(A. Winters, personal communication, February 19, 2020)

We feel sad, and a little guilty, but

We wanted to fight the school

And then we made us want to fight the school

And then we were tired

And then we were sad

And then we was tired

And then we thought about how

This couldn't be another space where we were reminded of our commodified existence

So we changed it up

And our friends came to visit

And shared their skills

And we became a group

And then the money ran out

And they took away our space

So now we exist

In a group chat

We feel sad, and a little guilty, but 
we get agitated thinking about it now.

we run into members every once in the while

we all stay in touch

But mostly we confess our capacity.

And whose capacity should be tested? Is tested? Is questioned?

Your candle-making, dog-petting, aromatherapy sessions are sad attempts to disappear the language for our anger, and distract us from holding you accountable for our demise ${ }^{1}$

I wanted to strangle the guide as if he were the original guide. It took all my will.

(Brand, 2017, p. 43)

We grieve what could be

What may never be

We grieve the memories that were never created

But push, we push through

We organize

We decolonize

We continue to hold space and demand accountability

We work without rest

"No one is ever transported to a perfect world where all problems are solved, where the past is over, and where the future is all sweet perfection neatly organized according to nicely-sounding-on-paper rules" (Gordon \& Davis, 2004, p. 196).

What if we started from the space beyond this, like imagining it, living it, and bringing it to life.

Yet in the rooms the guide was irrelevant, the gods woke up and we felt pity for them, and affection and love; they felt happy for us, we were still alive.

(Brand, 2017)

(What is accountability then)

This shift occurred when we were challenged by our academic advisor by the question, "What are y'all doing in the place that y'all are in?" We had our mind fixated on the space that we yearned for within our academic experiences and just in life in general to navigate and process our location, when we were girl and teen. We shifted from this mystical space that we wanted to create, to looking at our current location to address current needs. ${ }^{2}$

Yes, we are still alive we said.

(Brand, 2017)

in light of the backwardness of having to find ways to exist when we are already here

(Tesfaye, 2019)

There are too many moments where we surveil our bodies

Black bodies in space

Negotiating kinship and power

Black bodies surveilled

In space

Hold space

Code switch

We ain't playin wit you

We sit with 
Sit wit

We

Our

Selves

$$
\begin{gathered}
\text { memories } \\
\text { histories } \\
\text { locations } \\
\text { bodies } \\
\text { trauma }
\end{gathered}
$$

Being in a position or location where we as BLACKETY-BLACK-BLACK art therapists have to navigate the same systems as the Communities we work for. Locations that position us from an outsider-within social location (as cited in Collins, 2009).

Holding an outsider-within social location, there are moments that occur that make us feel like, "What are we doing here?" "Are we supposed to be here?"

We meet for the first time

In the waiting room

You were waiting for us

And I was waiting for you

You see us and we see you

Sometimes with looks of surprise

Sometimes with looks of relief

Sometimes with looks of suspicion

Or all three simultaneously

(Is this where self-preservation comes into play?)

I wonder how we break the tension

Sometimes

You look at me and say hello

Sometimes

I look at you and say hello

Sometimes

So

I wonder what it would be like if we talked it out instead

You make another popsicle stick heart and

We pretend that we both definitely don't know that

You and I are the only black women here ${ }^{3}$

(Is this where self-preservation comes into play?)

You are still alive, they said. Yes we are still alive. They looked at us like violet; like violet teas they drank us. We said here we are. They said, you are still alive. We said, yes, yes we are still alive. How lemon, they said, how blue like fortune.

(Brand, 2017)

“Are you sure, sweetheart, that you want to be well?... Just so's you're sure, sweetheart, and ready to be healed, cause wholeness is no trifling matter. A lot of weight when you're well" (Bambara, 1992).

They said with wonder and admiration, you are still alive, like hydrogen, like oxygen, We stood there for some infinite time. We did weep, but that is nothing in comparison. 
We rage often

You may see it, you may not

What's up?

It says hello often often

What's up?

Our children were taken away

What's up?

We have a history of abuse

What's up?

We write petitions

What's up?

We are Black

Black rage, we rage Blackly

We organize, we rage

We set boundaries, we rage

We demand that our needs be met, we rage

"Per my previous email," we rage

We grieve, we rage

We do other people's labor, we rage

We hold space for each other, we rage

We cry, we rage

Is our labor only meant to fulfill a capitalist structure? What are we doing in the place that we are? Are we here to merely be underpaid, overworked, and under resourced? How do we apply community care practices to systems that thrive on individualistic approaches? We told ourselves when we graduated from school that we no longer wanted our starting point to be whiteness or critiquing whiteness. We work collectively to create experiential spaces, participate in collective-reflectivity, we write petitions, we make curriculums, and we honor our bill of rights.

the relational navigation that occurs in the therapy room.

Reflections from December 6, 2019:

Sometimes crying feels like the response our body needs, but most of the time all we can feel are the emotions welling and stirring up inside of us. How old are you? How do you stay so positive with all that you do? We honestly don't know. We don't know how we hold it all together. We have the secret wish that we could let the neatly tied bow unloose and let all the pieces scatter about. Sometimes we wish we could just be someone for us and not for anyone else. We get so frustrated with our body's betrayal. We think that we're happy and that things are going well in our life. Our body is not matching how we feel.

\section{I need trust}

I need rest

I need affirmation

D. Swan: I think that's the y'allism.

Kuumba: Yea

D. Swan: Y'all get it. And I get what you're saying. When people are like ...

Black girl do you want to be free? 


\section{1}

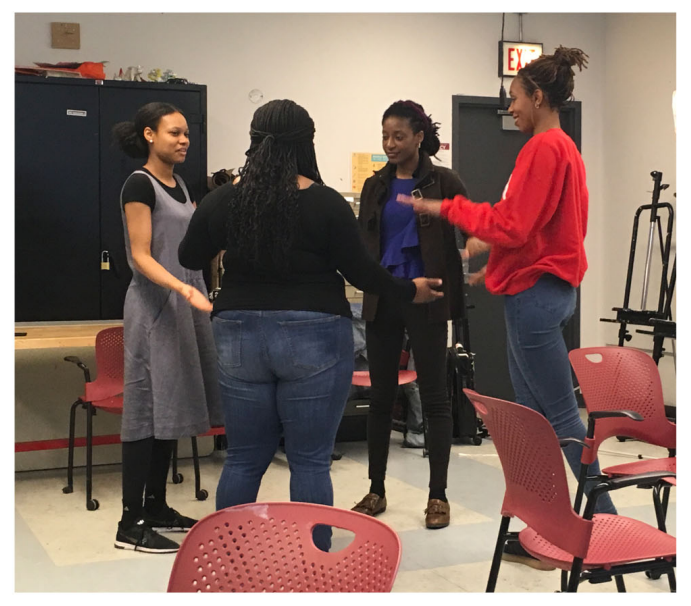

2

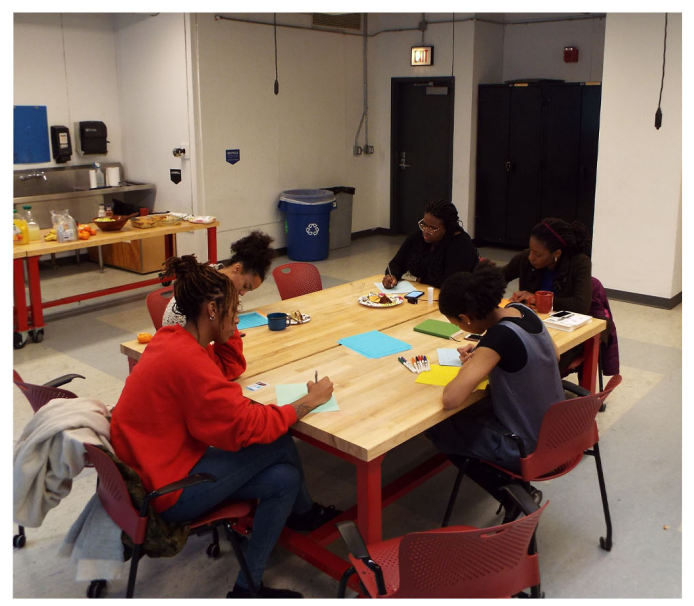

3

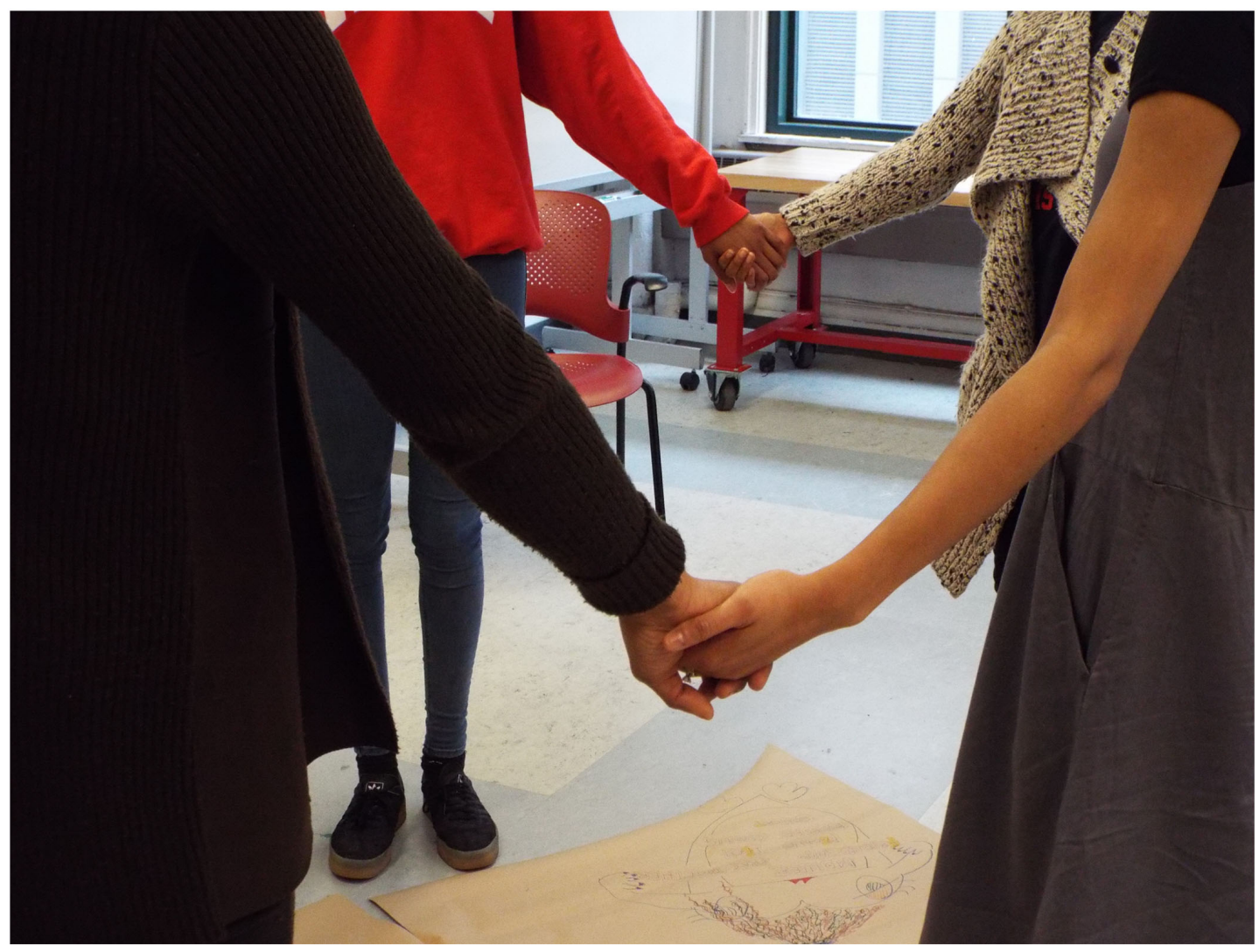




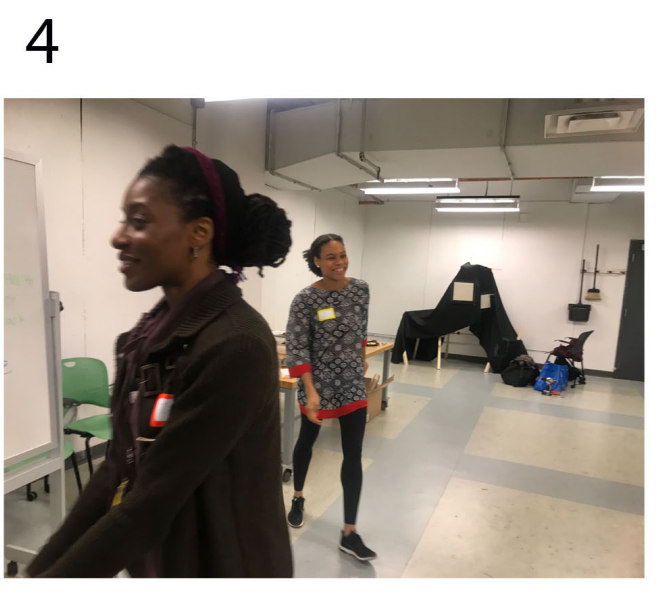

\section{5}

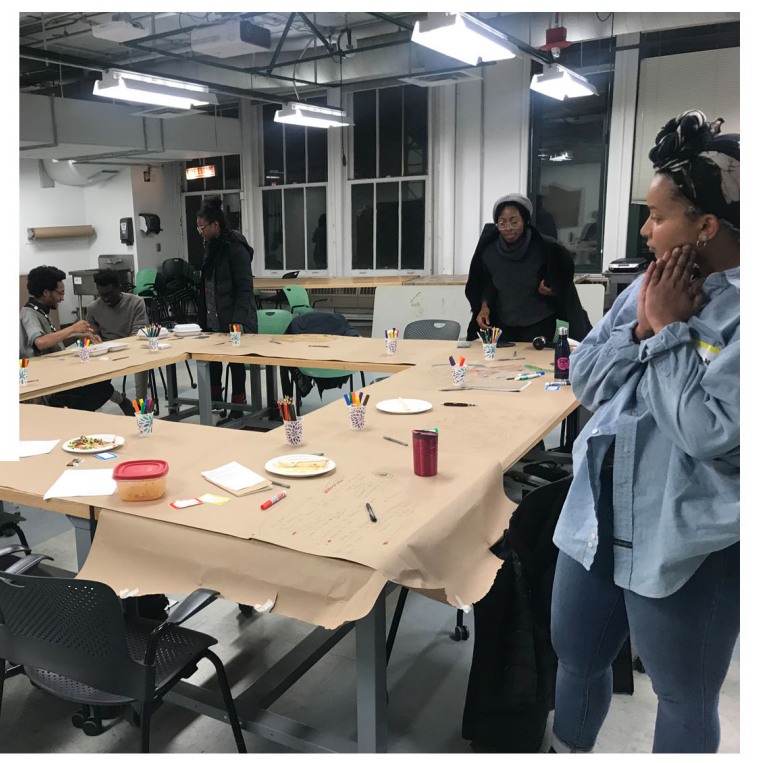

6

\section{7}

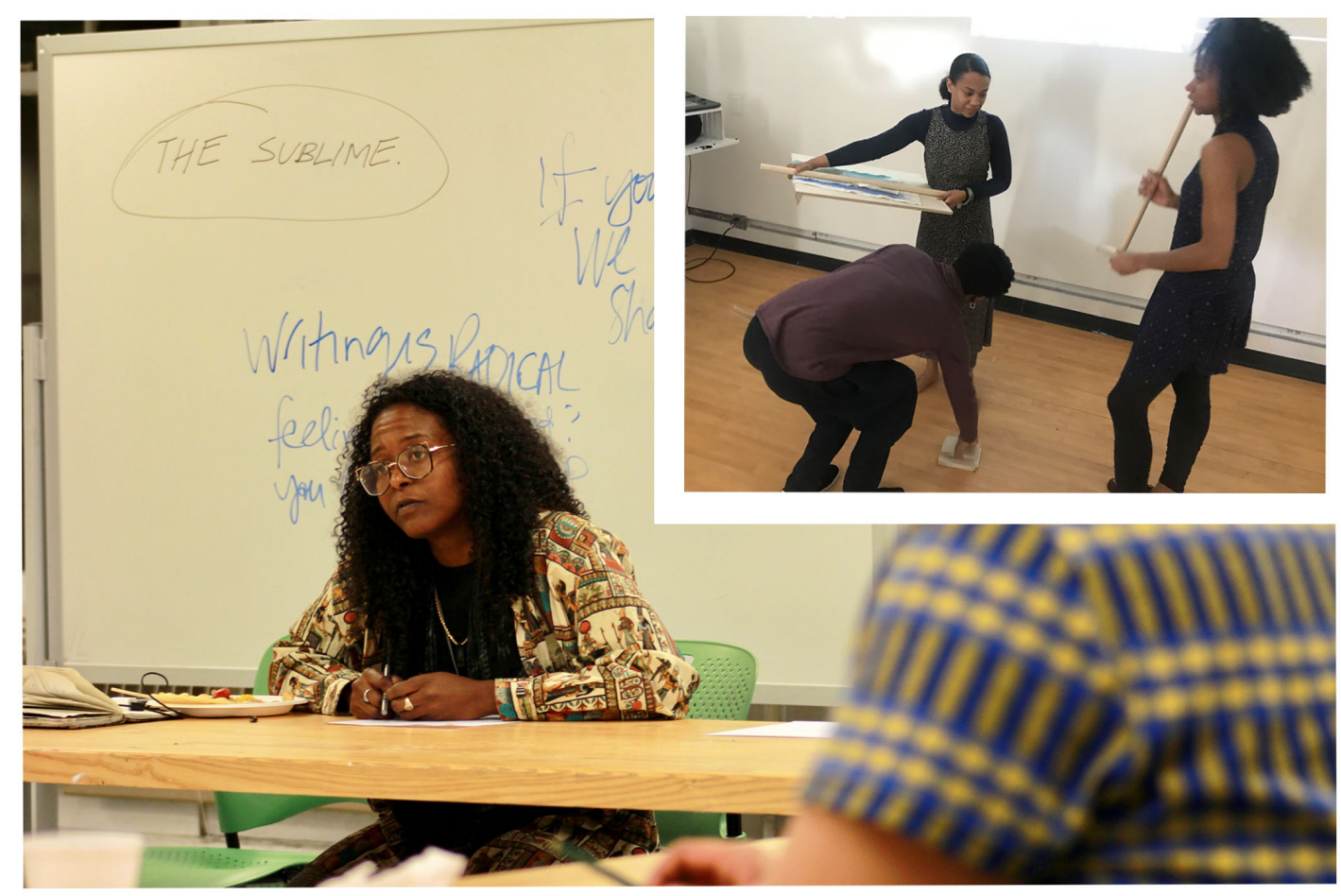


8

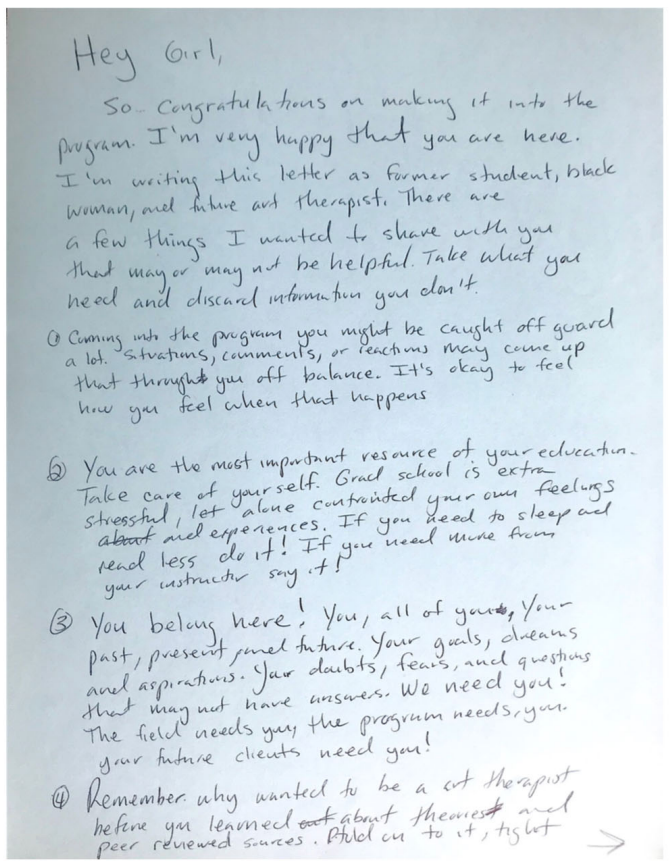

\section{9}

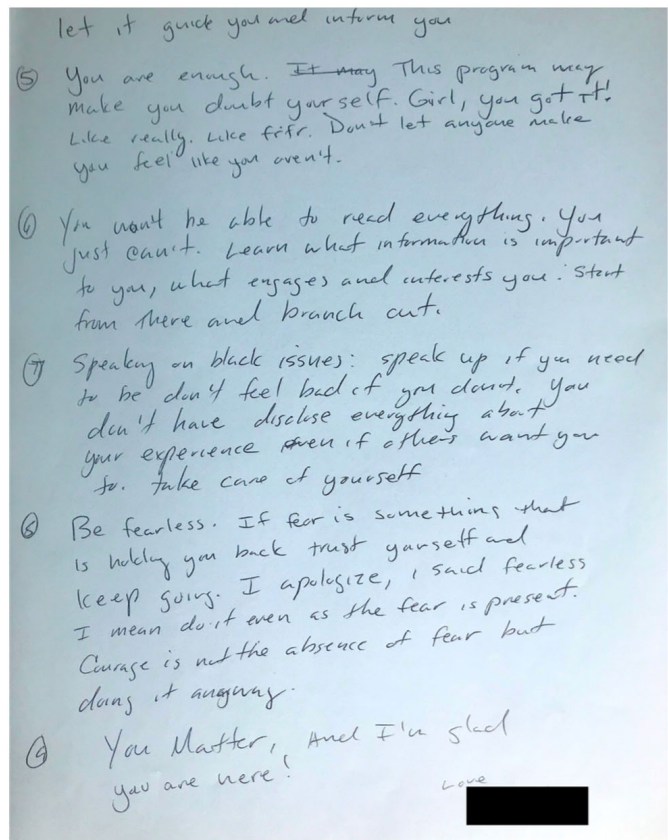

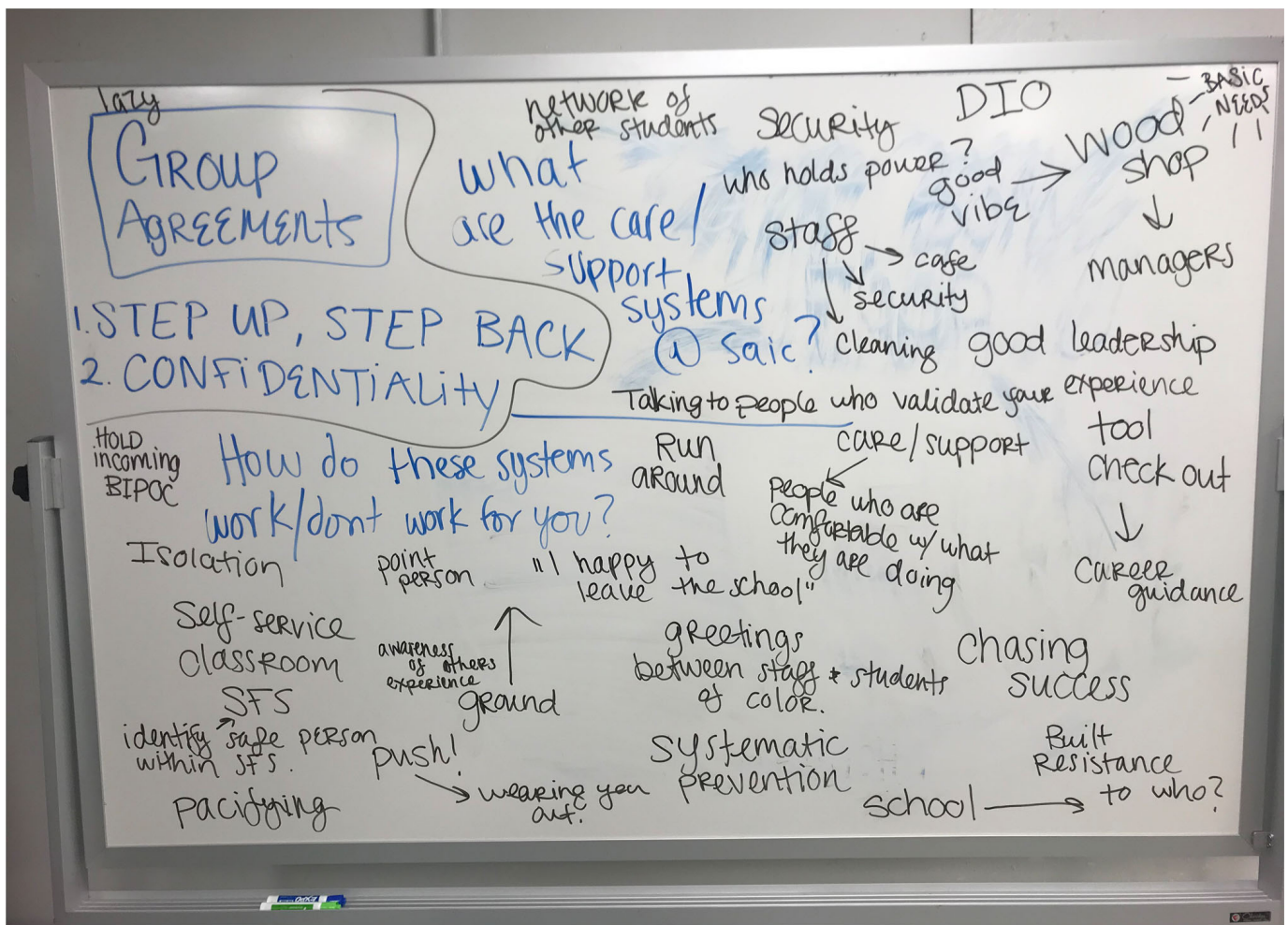




\section{1}

\section{Hey Ya'll}

Welcome yet again to the Ars therapy progrem. personally wish you well throughout the joumey to beoming a mental health professiomal. The challenges with finding your place in this envivonment vill be eye oeening and often rewarding if given the space. I encourage you to give yourself space to practice what it means to be an aurist and strelent I've come to conclude through my own experience that tunnel vision is best used when there is upport. Stand rooted in your cause.

you are resilient

you are valid

with bove and the bees wishes, 


\section{Image descriptions}

1. Four Black women standing in a circle playing a hand game in the opening ritual to the sister circle. Sister Circle 2019 at SAIC. Photographed by Larissa JohnsonAkinremi.

2. Five Black women sitting around a large square table writing letters to future Black art therapy students. Sister Circle 2019 at SAIC. Photographed by Crystle Diño.

3. Five Black women holding hands in the sister circle's closing ritual. Sister Circle 2019 at SAIC. Photographed by Crystle Diño.

4. Two Black women smiling and standing in a white classroom. BIPOC Makespace 2019 at SAIC. Photographed by Johanna Tesfaye.

5. Black students standing and sitting in conversation around a large square table covered in craft paper. BIPOC Makespace 2019 at SAIC. Photographed by Leah Amaral.

6. Black femme sitting at a table, in front of a white dry erase board. She is facilitating a writing workshop. BIPOC Makespace 2019 at SAIC. Photographed by Caitlyn Johnson.

7. Three Black women helping each other with a performance project. Performance class, fall 2019 at SAIC. Photographed by Johanna Tesfaye.

8. A letter on light blue paper with black pen, written by a Ujima. She is giving advice and affirmation to a future Black art therapy student (part 1). Sister Circle 2019 at SAIC. Photographed by Johanna Tesfaye.

9. A letter on light blue paper with black pen, written by a Ujima. She is giving advice and affirmation to a future Black art therapy student (part 2). Sister Circle 2019 at SAIC. Photographed by Johanna Tesfaye.

10. Large white dry-erase board outlining care and support systems at SAIC. BIPOC Makespace 2019 at SAIC. Photographed by Leah Amaral.

11. A letter on light blue paper with multi-color markers, written by D. Swan. She is giving advice and affirmation to a future Black art therapy student. (part 2). Sister Circle 2019 at SAIC. Photographed by Leah Amaral.

\section{About the authors}

Leah Amaral and Johanna Tesfaye are Chicago-based creative practitioners and collaborators. Amaral is a recent graduate from the Art Therapy and Counseling masters program at the School of the Art Institute of Chicago. When pursuing her Master's degree she understood that her position as a student was where her activism was. To address issues of equity and difference within art therapy education at a PWI, Amaral created Sister Circle in March 2019. Her work is understood from Black feminist ecological thought and womanist performance pedagogy; centering the experiences, knowledge, and stories of Black women and girls. Amaral currently works as a trauma informed clinical art therapist supporting families in reunification therapy. Amaral's current body of work explores grief, loss, and cycles of violence through poetry, digital media, and memory as material to create an archival site as an avenue to process personal and collective experiences.

Tesfaye is currently pursuing her masters in Art Therapy and Counseling at the School of the Art Institute of Chicago. Tesfaye's artistic, professional work, and research focuses on 'return', collective memory, and memory performance as care. Tesfaye works as a Northstar program coordinator and anti-oppression trainings curriculum builder \& facilitator at the Chicago Freedom School. She is also serving as a board member on Y'all Rock Carbondale as part of the Girls Rock Camp Alliance, an international membership network of youth-centered arts and social justice organizations. Tesfaye is the recipient of the 2018 SAIC Belonging \& Compassion Grant and was 
named a 2019 Association for Contemplative Mind in Higher Education Social Justice Scholar.

\section{Notes}

1. In response to the lack of institutional support and care for Black, Brown, and/or Indigenous students of Color at PWIs, Tesfaye called a dinner for graduate students and faculty of color from the Art Therapy and Counseling department at the School of the Art Institute of Chicago (SAIC) to meet early Fall 2019 to address their concerns. Inspired by the dinner, the author created BIPOC Makespace (Spring 2019-Spring 2020) as a recipient of the Belonging \& Compassion Grant. The space was for students to eat together, connect with students and alum across departments, check-in and talk about their experience at SAIC, and host guest facilitators and artists to share their practice.

2. After a call to action given in a personal conversation with her academic advisor about her experience as an art therapy student. Amaral was reminded that her position as a student is where her activism is. To address issues of equity and difference within art therapy education at a PWI, author created Sister Circle (March 30, 2019). This identity-affirming counter-space was created as a site of resistance. Giving Black art therapy students the space to share a meal, share stories about their experience as art therapy students, affirm and witness each other, dialogue about belongingness and care, and strategize towards action. The process of creating the Sister Circle is documented in author's (2019c) Master's Thesis, Art Therapy Sister Circle: Creating an Identity-Affirming Counter-space for Black Women Art Therapy Graduate Students.

3. ArtWorks is a weekly drop-in open studio held at the Harold Washington Library in downtown Chicago. It's mission, as stated on the library's website (Harold Washington Library, 2017), is "to cultivate inclusive communities through the arts and cultural exchange" and "to foster the development of understanding and compassion between people, despite social and cultural differences." Both authors participated as art therapy graduate students for their practicum.

\section{References}

Amaral, L. (2019a). Survival sketch [Drawing].

Amaral, L. (2019b). A transcription of the story circle audio recording: Sister Circle on March 30, 2019 (D. Swan, Umoja, Kuumba, \& sisters) [Transcript].

Amaral, L. (2019c). Art therapy sister circle: Creating an identity-affirming counter-space for Black women art therapy graduate students (Master's thesis). Retrieved from SAIC Digital Collections.

Bambara, T. C. (1992). The salt eaters. Vintage Books.

Brand, D. (2017). Excerpts from The Blue Clerk. Transition, 124, 38-44, https://doi.org/ 10.2979\%2Ftransition.124.1.12.

Collins, P. H. (2009). Black feminist thought: Knowledge, consciousness, and the politics of empowerment (2nd ed.). Routledge.

Gordon, A., \& Davis, A. (2004). Keeping good time: Reflections on knowledge, power, and people (1 ed.). Taylor \& Francis. https://doi.org/10.4324/9781315633787.

Harold Washington Library. (2017, May 19). ArtWorks Studio Moving to Wednesdays at HWLC.

Retrieved from https://www.chipublib.org/news/artworks/

Tesfaye, J. (2019). Untitled [Painting]. 